\title{
Developmental Indices of Nutritionally Induced Placental Growth Restriction in the Adolescent Sheep
}

\author{
RICHARD G. LEA, LISA T. HANNAH, DALE A. REDMER, RAYMOND P. AITKEN, \\ JOHN S. MILNE, PAUL A. FOWLER, JOANNE F. MURRAY, AND JACQUELINE M. WALLACE \\ Ovine Pregnancy Group [R.G.L., L.T.H., R.P.A., J.S.M., J.M.W.], Rowett Research Institute, Bucksburn, \\ Aberdeen AB21 9SB, Scotland, Department of Animal and Range Sciences [D.A.R.], North Dakota State \\ University, Fargo, North Dakota, 58105, U.S.A., Department of Obstetrics and Gynaecology [R.G.L., \\ P.A.F.], University of Aberdeen, Foresterhill, Aberdeen, AB25 2ZD, Scotland, Departments of Basic \\ Medical Sciences and Clinical Development Sciences [J.F.M.], St. George's Hospital Medical School, \\ London SW17 ORE, UK
}

\begin{abstract}
Most intrauterine growth restriction cases are associated with reduced placental growth. Overfeeding adolescent ewes undergoing singleton pregnancies restricts placental growth and reduces lamb birth weight. We used this sheep model of adolescent pregnancy to investigate whether placental growth restriction is associated with altered placental cell proliferation and/or apoptosis at d 81 of pregnancy, equivalent to the apex in placental growth. Adolescent ewes with singleton pregnancies were offered a high or moderate level of a complete diet designed to induce restricted or normal placental size at term, respectively. Bromodeoxyuridine (Brd-U) was administered to $\mathrm{H}$ and $\mathrm{M}$ ewes $1 \mathrm{~h}$ before slaughter. Placental tissues were examined for a) Brd-U (immunohistochemistry) and b) apoptosis regulatory genes by in situ hybridization, Northern analyses (bax, mcl-1), immunohistochemistry, and Western analyses (bax). Quantification was carried out by image analysis. Total placentome weights were equivalent between groups. Brd-U predominantly localized to the trophectoderm and was significantly lower in the H group. Bax and mcl-1 mRNA were localized to the
\end{abstract}

\section{ABSTRACT}

maternal-fetal interface. Bax protein was significantly increased in the $\mathrm{H}$ group and predominant in the uninuclear fetal trophectoderm. These observations indicate that reduced placental size at term may be due to reduced placental cell proliferation and possibly increased apoptosis occurring much earlier in gestation.

(Pediatr Res 57: 599-604, 2005)

Abbreviations
Bax, pro-apoptosis gene
Bcl-2, anti-apoptosis gene
BNC, binucleate cell
Brd-U, bromodeoxyuridine
DDT, dichlorodiphenyltrichloroethane
IUGR, intrauterine growth restriction
mcl-1, myeloid cell lymphoma 1
NBF, neutral buffered formalin
PSPB, pregnancy-specific protein B
SSC, saline sodium citrate

Human adolescent pregnancies are characterized by a number of adverse perinatal outcomes, including an increased incidence of preterm delivery, low birth weight due to IUGR, small-forgestational-age infants, and malformations (1). These infants suffer a number of neonatal complications requiring considerable medical attention for the first year of life $(2,3)$. This problem persists even when pregnant teenagers are socioeconomically matched to pregnant adults and shown to have better health and

Received April 17, 2003; accepted June 17, 2004.

Correspondence: Richard G. Lea, Ph.D., Ovine Pregnancy Group, Rowett Research Institute, Greenburn Rd., Bucksburn, Aberdeen, AB21 9SB, Scotland; e-mail: R.Lea@rri.sari.ac.uk

Supported by the Scottish Executive Environment and Rural Affairs Department (SEERAD) as part of the core funding to the Rowett Research Institute.

DOI: 10.1203/01.PDR.0000155949.08547.66 suffer from fewer diseases (4). Therefore, one risk factor is the youth of the mother rather than any socioeconomic correlates. However, poor pregnancy outcome in adolescent girls has also been linked to the nutrition and/or growth status of the mother at the time of conception (5). Moreover, the majority of cases of IUGR, irrespective of maternal age, are attributed to inappropriate growth of the placenta, which results in an inadequate nutrient supply to the fetus $(6,7)$. Although the mechanisms by which restricted placental growth results in IUGR are poorly understood, clinical investigations in the human are ethically constrained, and studies of placental growth in human adolescents are difficult to control. For example, nutritional deficiencies in adolescent populations from developing and developed countries may differ. This dictates the need for a suitable and well-controlled animal model. 
We have developed a highly controlled sheep model of adolescent pregnancy where young growing ewes carrying singleton pregnancies are placed on a high or moderate amount of a balanced diet to promote rapid or low maternal growth, respectively. Those animals on the high-intake diet suffer a major reduction in placental mass at term and have significantly smaller lambs than those animals on moderate (control) diets (8). In addition, total placental weight and lamb birth weights are highly correlated, indicating that restricted placental growth is the primary cause of IUGR in these pregnancies $(9,10)$. Furthermore, our preliminary studies on adult sheep pregnancies indicate that nutritionally induced placental growth restriction is specific to adolescent pregnancies, i.e. the animals must still be growing (11). Although these findings may initially appear paradoxical, in the human, birth weight is significantly reduced in primiparous and multiparous adolescent girls who are still growing during pregnancy compared with age-matched nongrowing adolescents $(5,12)$.

The placenta of the sheep differs from the human in that it can be divided into discreet attachment sites where fetal chorion comes into contact with raised areas of nonglandular vascularized endometrium called caruncles. However, within the placentome, the villous tree is structurally similar to that of the human (reviewed in 6). In the development of the placenta, the balance between cell proliferation and cell death by apoptosis is critical (13). Apoptosis is regulated in part by a large family of genes, many of which belong to the bcl-2 family. These proteins can be either pro- or antiapoptotic and they form homo- and heterodimers where one protein counteracts the activity of the other (13). In the human, IUGR has been associated with the altered expression of some of these genes in the placenta as well as increased apoptosis, decreased proliferation, and decreased vascularization (14-18).

The purpose of this study was to use the sheep adolescent model to investigate whether the predicted placental growth restriction in rapidly growing adolescents is associated with altered placental cell proliferation and/or the expression of apoptosis regulatory genes at $\mathrm{d} 81$ of pregnancy. This stage of gestation represents the apex of placental growth (19) and thus a window when altered placental proliferation and/or apoptosis would have a greater impact on placental growth. Placentas were examined for proliferative activity and the expression of proapoptotic bax and antiapoptotic mcl-1.

\section{METHODS}

Animals and experimental design. All procedures were licensed under the UK Animals (Scientific Procedures) Act of 1986. Embryos recovered on d 4 after estrus from superovulated adult ewes (Border Leicester $\times$ Scottish Blackface), which had been inseminated by a single sire (Dorset Horn), were synchronously transferred, singly, into the uteri of adolescent recipient ewe lambs (Dorset Horn $\times$ Mule) as previously described (8). This protocol ensured that placental and/or fetal growth were not influenced by varying fetal number or partial embryo loss. In addition, the use of a single sire and a limited number of donors maximized the homogeneity of the resulting fetuses. All animals were housed in individual pens under natural lighting conditions $\left(57^{\circ} \mathrm{N} 2^{\circ} \mathrm{W}\right)$. At the start of the study, the peripubertal adolescent recipient ewes were $225 \pm 3 \mathrm{~d}$ old with a mean live weight of $45 \pm 0.6 \mathrm{~kg}$. Immediately after embryo transfer, the adolescent ewes were allocated to one of two dietary treatments so that the two groups were similar with respect to live weight, body condition score (20), and ovulation rate at the time of embryo transfer. Care was also taken to balance for donor embryo source where possible. Recipient ewes were offered individually a high $(\mathrm{H})$ or a moderate $(\mathrm{M})$ level of a complete diet (8). The aim was to achieve a rapid maternal growth rate of $250-300 \mathrm{~g} / \mathrm{d}$ in the $\mathrm{H}$ group and to maintain a low growth rate of $50-75 \mathrm{~g} / \mathrm{d}$ in the $\mathrm{M}$ group during the first $100 \mathrm{~d}$ of gestation. The moderate (control) dietary level was predicted to optimize placental and fetal growth in this genotype. The complete diet provided an estimated 10.2 MJ metabolizable energy per kilogram dry matter (DM) and $136.6 \mathrm{~g}$ crude protein per kilogram $\mathrm{DM}$, and had an average dry matter of $85.5 \%$. All ewes were offered their feed in two equal portions at $0800 \mathrm{~h}$ and $1600 \mathrm{~h}$ daily, and the daily feed refusal was weighed and recorded before the $0800 \mathrm{~h}$ feed. Ewes in the M group were offered their experimental diets starting immediately after embryo transfer, whereas the level of feed offered to ewes in the $H$ group was increased gradually over a 2 -wk period until the level of daily feed refusal was approximately $15 \%$ of the total offered (equivalent to ad libitum intakes). Ewes were weighed weekly and their body condition score was assessed monthly. The level of feed offered was adjusted three times each week according to both live weight changes and feed refusals. At approximately $50 \mathrm{~d}$ of gestation, pregnancy was confirmed by transabdominal ultrasonography. Pregnancies were established and maintained in a total of $14 \mathrm{H}$ and $13 \mathrm{M}$ dams.

Tissue collection and fixation. Pregnant ewes were killed at d 81 of gestation. To determine cell proliferation, a subset of ewes ( $n=6$ per group) were infused with Brd-U ( $5 \mathrm{mg} / \mathrm{kg}$ body weight, dissolved in PBS to form a saturated solution of $16.7 \mathrm{mg}$ Brd-U/mL, $\mathrm{pH} 7.0$ ), via a catheter inserted in the jugular vein, exactly $1 \mathrm{~h}$ before lethal injection $(21,22)$. Animals were killed by intravenous administration of an overdose of sodium pentobarbitone $(20 \mathrm{~mL}$ Euthesate; 200 mg pentobarbitone/mL; Willows Francis Veterinary, Crawley, UK) and exsanguination was carried out by severing the main blood vessels of the neck. The gravid uterus was removed immediately and opened. The fetus was killed by intracardiac administration of sodium pentobarbitone $(5 \mathrm{~mL}$ Euthesate). The umbilical cord was clamped and the fetus was removed, dried, and weighed. The uteri were dissected and 8 or 12 representative placentomes removed from the entire length of the gravid uterine horn [equivalent to $13 \pm$ $1.01 \%$ and $13.8 \pm 0.90 \%$ (mean \pm SEM) of the total placentome population in $\mathrm{M}$ versus $\mathrm{H}$ dams, respectively]. Eight placentomes were then either halved or sliced into 7-mm cross-sections and a) immersion fixed in Carnoy's fixative for $6 \mathrm{~h}$, followed by $70 \%$ ethanol (Brd-U-treated ewes only), or b) immersion fixed in $10 \% \mathrm{NBF}$ for $24 \mathrm{~h}$, followed by $70 \%$ ethanol before routine wax embedding. Four whole placentomes were snap frozen in liquid nitrogen-cooled isopentane and subsequently stored at $-80^{\circ} \mathrm{C}$. All remaining placentomes were dissected and then weighed to calculate the total placentome weight.

Cloning of ovine mcl-1 and bax. cDNA fragments of mcl-1 and bax were generated from sheep ovarian RNA by reverse transcriptase PCR. $M c l-1$ cDNA was amplified using the primer pair, 5'-TTCTCGAGTRATGRTCCATG-3' and 5'-CATCAGYAATGTGCTGCTGG-3', corresponding to bases 729-748 and 972-991 of both mouse and human mcl-1 mRNA (Accession Numbers U35623 and L08246, respectively). Bax cDNA was amplified using the primer pair 5'-GGTTTCATCCAGGATCGAGACG- 3' and 5'-GGCAGACCGTGACCATCTTTGT- 3' corresponding to bases 85-106 and 509-530 of both mouse and human bax mRNA (Accession Numbers L22472 and L22473, respectively). The $m c l-1$ and bax cDNA were cloned into pCRII-Topo vector by following the manufacturer's instructions (Invitrogen, Carlsbad, CA) and sequenced (Accession Numbers AF144097 and AF163774, respectively).

RNA extraction and Northern analyses. Frozen placental tissue was pulverized and TRI-reagent (Sigma Chemical, St. Louis, MO) was added to $100 \mathrm{mg}$ of each sample. The sample was then homogenized and RNA extracted according to the TRI-reagent manufacturer's protocol. Fifteen micrograms of total RNA were separated on a $1.0 \%$ agarose gel containing formaldehyde and electrophoretically transferred to a nylon membrane (Hybond, Amersham Pharmacia Biotech UK, Ltd., Little Chalfont, Buckinghamshire, UK). Probes for $m c l-1$ and bax were labeled with $\left[\alpha-{ }^{32} \mathrm{P}\right]$ dCTP using Ready-To-Go DNA labeling beads (Amersham Pharmacia Biotech UK, Ltd.). Hybridizations were carried out at $42^{\circ} \mathrm{C}$ according to standard protocols. The blots were washed to high stringency in $0.1 \times \mathrm{SSC}$ (saline-sodium citrate buffer) plus $0.1 \%$ SDS at $42^{\circ} \mathrm{C}$ and imaged on a wire proportional counter (Packard Instant Imager, Packard Instrument Co., Meriden, CT). The mRNA were quantified by measuring the amount of radioactivity hybridizing to the bands on the Northern blot and correcting for loading by reprobing with a probe for $18 \mathrm{~s}$ rRNA.

In situ hybridization. The plasmids were linearized with BamH1 or EcoRV for transcription with T7 or Sp6 RNA polymerase to generate antisense and sense probes, respectively. Probes were radioactively labeled with ${ }^{35} \mathrm{~S}$ using a commercially available kit (Promega UK Ltd., Southampton, UK).

For each gene, three slides per sheep were collected, with one section of placentome per slide. This enabled all animals to be included in a single in situ experiment with two antisense controls and one matched sense control per animal. In situ hybridization was carried out as previously described $(23,24)$. In brief, frozen sections $(14 \mu \mathrm{m})$ were taken up to room temperature (approximately $1 \mathrm{~h}$ ) and fixed in $4 \%$ paraformaldehyde/PBS at $4^{\circ} \mathrm{C}$ for $20 \mathrm{~min}$. Slides 
were then acetylated with $0.25 \%$ acetic anhydride (Sigma Chemical) in $0.1 \mathrm{M}$ triethanolamine (10 $\mathrm{min})$, dehydrated, and air-dried.

Sections were hybridized with $10^{6} \mathrm{cpm}\left[^{35} \mathrm{~S}\right]$-RNA in $60 \mu \mathrm{L}$ hybridization buffer at $59^{\circ} \mathrm{C}$ overnight. The next day, sections were washed in $4 \times \mathrm{SSC}$ for $4 \times 5 \mathrm{~min}$, incubated in ribonuclease A (Sigma Chemical) solution $(0.02$ $\mathrm{mg} / \mathrm{mL}$ in $0.01 \mathrm{M}$ Tris-HCl, $0.5 \mathrm{M} \mathrm{NaCl}, 0.001 \mathrm{M}$ EDTA, $\mathrm{pH}$ 7.6) for $30 \mathrm{~min}$ at $37^{\circ} \mathrm{C}$, and washed in $2 \times$ SSC-DTT (SSC with $1 \mathrm{mM}$ DTT; Sigma Chemical) for $2 \times 5 \mathrm{~min}$. Slides were immersed in $1 \times$ SSC-DDT for $10 \mathrm{~min}$, $0.5 \times$ SSC-DTT for $10 \mathrm{~min}$, and washed at $60^{\circ} \mathrm{C}$ with $0.1 \times$ SSC-DTT for 30 min before cooling in $0.1 \times \mathrm{SSC}$. Sections were dehydrated in graded ethanols, air dried, and exposed to Kodak BioMax film (Eastman Kodak, Rochester, $\mathrm{NY}$ ) for $5-10 \mathrm{~d}$.

Quantification of in situ hybridization. Autoradiographs of sections including ${ }^{14} \mathrm{C}$ microscale standards $(30-862 \mathrm{nCi} / \mathrm{g}$; Amersham Pharmacia Biotech UK, Ltd.) were scanned on a Umax Power Look II (UMAX Data Systems, Fremont, CA) using Adobe Photoshop (Adobe Systems, Mountain View, CA). Image-Pro Plus software (MediaCybernetics, Silver Spring, MD) was used to convert tissue equivalent radioactivity levels of scanned autoradiographic films to OD of autoradiographs based on the standard curve generated from the ${ }^{14} \mathrm{C}$ autoradiographic microscale (25-27). OD values from control sections incubated with sense probe were designated background labeling and subtracted from those obtained using the antisense probe. For microscopy, slides were dipped in K5 nuclear emulsion (Ilford, Cheshire, UK) and exposed for $2 \mathrm{wk}$ at $4^{\circ} \mathrm{C}$. Slides were then developed in Kodak Dektol developer (Eastman Kodak) and fixing solution (Eastman Kodak), 5 min in each, and counterstained with hematoxylin Z (CellPath, Newton, Powys, Wales).

Immunohistochemistry. Placental sections $(5 \mu \mathrm{m})$ were mounted on polylysine/gelatin double-coated slides (one section per slide). Following routine de-waxing, antigen retrieval procedures were used for the Brd-U $(2.0 \mathrm{M} \mathrm{HCl}$, $30 \mathrm{~min})$ and bax epitopes [microwaving sections in $0.01 \mathrm{M}$ citrate buffer $(\mathrm{pH}$ 6.0) on full power for $2 \times 5 \mathrm{~min}$ ]. Sections were placed in a DAKO Autostainer and incubated with mouse anti-BrdU (Roche Diagnostics, Basel, Switzerland) at 1:50 or rabbit anti-bax (Santa Cruz Biochemicals, Santa Cruz, CA) at 1:50 for $30 \mathrm{~min}$. Antibody binding was visualized using the ChemMate peroxidase/DAB detection system (DakoCytomation Ltd., Ely, Cambridgeshire, UK), and all sections were counterstained using hematoxylin. Negative controls were performed by replacing the primary antibodies with rabbit IgG at the same concentration. All animals were included in each experiment with one placentome section incubated with primary antibody and a selected number with nonspecific IgG.

The Brd-U staining was quantified by computer-aided image analysis using a Zeiss Axioplan microscope $(\times 20$ objective; Carl Zeiss Ltd., Welwyn Garden City, Hertfordshire, UK) and Hitachi HV-C20 color camera (Hitachi Denshi America, Ltd., Woodbury, NY) connected to a computer running Image-Pro Plus software (MediaCybernetics). Quantification was carried out over 20 fields of view taken randomly and transversely across the central part of the placentome section. On each captured image, the total area of positively stained cells (brown color) was measured and expressed as a percentage of the total nuclear area stained with hematoxylin (purple color) and brown DAB substrate. Bax immunostaining was not conducive to this type of quantification.

One-dimensional gel electrophoresis (1-DE) and Western blotting. Snapfrozen whole ovine placentomes (one per ewe) were crushed on dry ice and sonicated in lysis buffer containing $0.01 \mathrm{M}$ Tris- $\mathrm{HCl}, \mathrm{pH}$ 7.4, 1 mM EDTA, 8 M Urea, 0.05 M DTT, $10 \%$ (vol/vol) glycerol 5\% (vol/vol) NP40, 6\%. The lysed proteins were processed using the Pierce PAGEprep clean up and enrichment kit (Perbio Science UK Ltd., Cramlington, Northumberland, UK) and electrophoresed $(15 \mu \mathrm{g} / \mathrm{lane})$ randomly on duplicate 15-lane 1-DE gels (Ready Gel, 4-15\% Tris HCl: Bio-Rad, Hemel Hempstead, UK) under reducing conditions. Two lanes of prestained molecular weight markers $\left(\mathrm{M}_{\mathrm{r}}\right)$ were run with each gel (SeeBlue Plus2, Invitrogen). The proteins were immediately transferred onto nitrocellulose (Sigma Chemical) membranes at $100 \mathrm{~V}$ for 75 min in transfer buffer $(25 \mathrm{mM}$ tris, $192 \mathrm{mM}$ glycine, $0.1 \%$ SDS, and $20 \%$ methanol). The membranes were processed using Vectastain ABC-AmP kits (Vector Laboratories Ltd., Peterborough, UK) according to kit instructions. Blocking was performed with casein solution and PBS diluted primary antibodies: 1) bax (N-20, Santa Cruz Biotechnology), 1:100, and 2) $\beta$-actin (Abcam Ltd., Cambridge, UK), 1:5000. After the primary antibody incubation (90 min, room temperature), protein bands were visualized chromogenically using kit biotinylated secondary antibodies and streptavidin-alkaline phosphatase. The Western blots were analyzed using Phoretix-1D Advanced software (NonLinear Dynamics Ltd., Newcastle-upon-Tyne, UK) to determine the band volumes. The values for bax were then normalized as a percentage of $\beta$-actin individually for each lane.

Statistical analyses. Image analysis data were analyzed using GenStat (VSN International Ltd., Hemel Hempstead, UK) or StatView (SAS Institute, Cary, NC) software. Data were tested for normal distribution and groups compared by ANOVA and standard posthoc $t$ tests where appropriate. Where data were not normally distributed, a nonparametric Mann-Whitney test was used. Pearson's correlation analysis was used to investigate potential sets of correlating data.

\section{RESULTS}

Maternal live weight and body condition. At embryo transfer, the mean live weight and body condition scores for ewes that conceived were $45 \pm 0.8$ and $46 \pm 0.9 \mathrm{~kg}$ and $2.3 \pm 0.04$ and $2.4 \pm 0.04$ score units in the $\mathrm{H}(n=14)$ and $\mathrm{M}(n=13)$ groups, respectively. At slaughter (d 81), mean live weights and body condition scores of ewes in the $\mathrm{H}$ and $\mathrm{M}$ groups were $68 \pm 1.1$ and $52 \pm 0.8 \mathrm{~kg}(p<0.001)$ and $2.9 \pm 0.04$ and $2.3 \pm$ 0 score units $(p<0.001)$, respectively. The mean live weight gains during the first $80 \mathrm{~d}$ of gestation for the $\mathrm{H}$ and $\mathrm{M}$ groups were $273 \pm 14$ and $67 \pm 4 \mathrm{~g} /$ day, respectively $(p<0.001)$.

Placental and fetal mass. At d 81 of gestation, total placentome weights were not significantly different $(\mathrm{H}: 703 \pm 48 \mathrm{~g}$ versus M: $658 \pm 36 \mathrm{~g}$ ). Nine and seven fetuses were male in the $\mathrm{H}$ and $\mathrm{M}$ groups, respectively, and there was no difference in fetal weight between groups at this stage of gestation (426 \pm 12.4 and $412 \pm 8.5 \mathrm{~g}$ for $\mathrm{H}$ and $\mathrm{M}$ groups, respectively).

Proliferation index: Brd-U immunolocalization. In all 12 ewes treated with Brd-U before slaughter, positive cells were predominantly localized to the fetal trophectoderm (Fig. 1, $a$
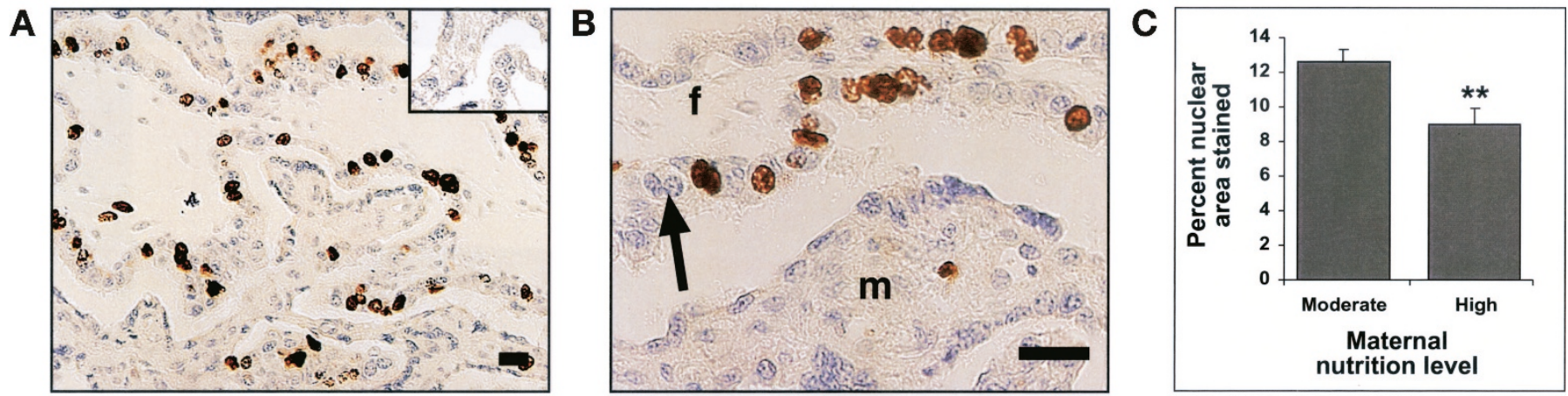

Figure 1. Immunolocalization and quantification of d-81 placental cells that have taken up Brd-U as a measure of cell proliferation. (A) Positive cells were predominantly localized to the fetal trophectoderm, however, some immunopositive cells were localized to the maternal caruncle. $(B)$ At higher magnification, a majority of positive trophectoderm cells were uninuclear. The arrow points to a Brd-U-negative BNC. $(C)$ Brd-U immunostaining expressed as percentage of total nuclear area in placentas from control and $\mathrm{H}$ animals $(* * p<0.01$, significantly lower in $\mathrm{H}$ group). Values are expressed as the mean \pm SEM. $F$, fetal cotyledon; $m$, maternal caruncle. Scale bar $=100 \mu \mathrm{m}$. Inset, IgG-negative control. 
and $b$ ). Examination of the sections at high power revealed that the positive trophectoderm cells were predominantly uninuclear, with few binuclear cells showing immunoreactivity (Fig. 1b). Some positive cells were also noted in the maternal caruncle and were localized sporadically to the stroma and vascular endothelium (Fig. 1, $a$ and $b$ ). Placentomes from $\mathrm{H}$ animals had significantly fewer Brd-U positive cells than placentomes from $\mathrm{M}$ animals (M: $12.6 \pm 0.7 \%$ versus $\mathrm{H}: 9.0 \pm$ $0.9 \%$ of tissue area Brd-U positive; $p<0$. 01; Fig. 1c). Irrespective of treatment group, the number of proliferating cells was negatively associated with maternal live weight gain $(r=0.637, n=12, p<0.05)$

Expression of mcl-1 and bax mRNA in d-80 placentome. Figure 2 shows the expression of mcl- 1 and bax mRNA in ovine placentome samples from 10 randomly selected animals (M: lanes 1, 5, 6, and 7; H: lanes 2-4 and 8-10). As published elsewhere, the $m c l-1$ and bax probes hybridized to principal transcripts of $3.5-4.0 \mathrm{~kb}$ and $1.5 \mathrm{~kb}$, respectively $(28,29)$. Comparison of the M group $(n=8)$ to the $\mathrm{H}$ group $(n=8)$ did not reveal any significant differences with respect to relative $m c l-1$ mRNA levels (M: $1.198 \pm 0.160$ arbitrary units verus $\mathrm{H}$ : $1.166 \pm 0.161$ arbitrary units; $p>0.05$ ). Similarly, no significant differences in relative bax mRNA levels were observed (M: $0.938 \pm 0.111$ versus $\mathrm{H}: 0.730 \pm 0.060 ; p>0.10$ ).

Detection of mcl-1 and bax mRNA by in situ hybridization. Marked hybridization for $m c l-1$ and bax mRNA was observed throughout the placentome. This is depicted at the autoradiograph level in Figure $3 a(m c l-1)$ and Figure $3 b$ (bax). Close examination of the sections under light- and dark-field conditions revealed that both $m c l-1$ (Fig. 3, $c$ and $e$ ) and bax (Fig. 3, $d$ and $f$ ) mRNA were localized predominantly to the maternalfetal interface, likely including the fetal trophectoderm. At the autoradiography level, sense controls exhibited little background (Fig. 3, $a$ and $b$ insets). Similarly, at the microscopy level, dark-field sense controls (Fig. $3 g$, mcl-1; Fig. 3h, bax) showed no signal above background levels. The specific activities of the mcl-1 and bax RNA probes were $1.302 \times 10^{9}$ and $1.256 \times 10^{9} \mathrm{cpm} / \mu \mathrm{g}$, respectively.

Comparative integrated OD analyses of the autoradiograph images did not reveal any significant differences in $\mathrm{mcl}-1$ mRNA between the $\mathrm{M}$ and $\mathrm{H}$ groups $(\mathrm{M}$ : 84,233 $\pm 11,023$

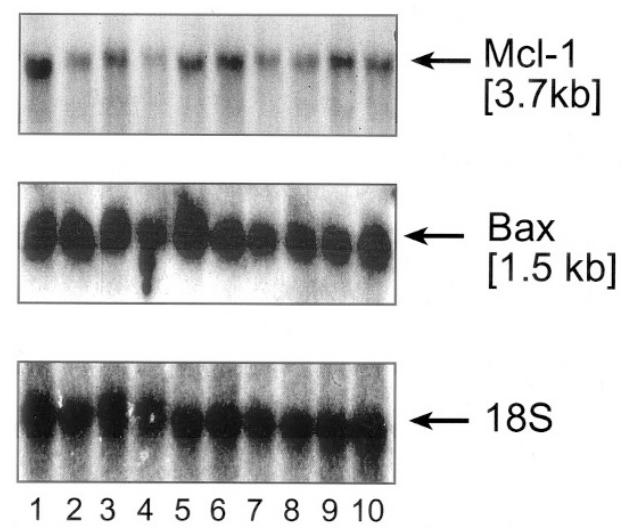

Figure 2. Northern blot showing mcl-1 and bax gene expression in 10 randomly selected d-81 ovine placentas (M: lanes 1, 5-7; H: lanes 2-4, 8-10). Blots were probed for $18 \mathrm{~s}$ mRNA (18S) to demonstrate equivalent loading.
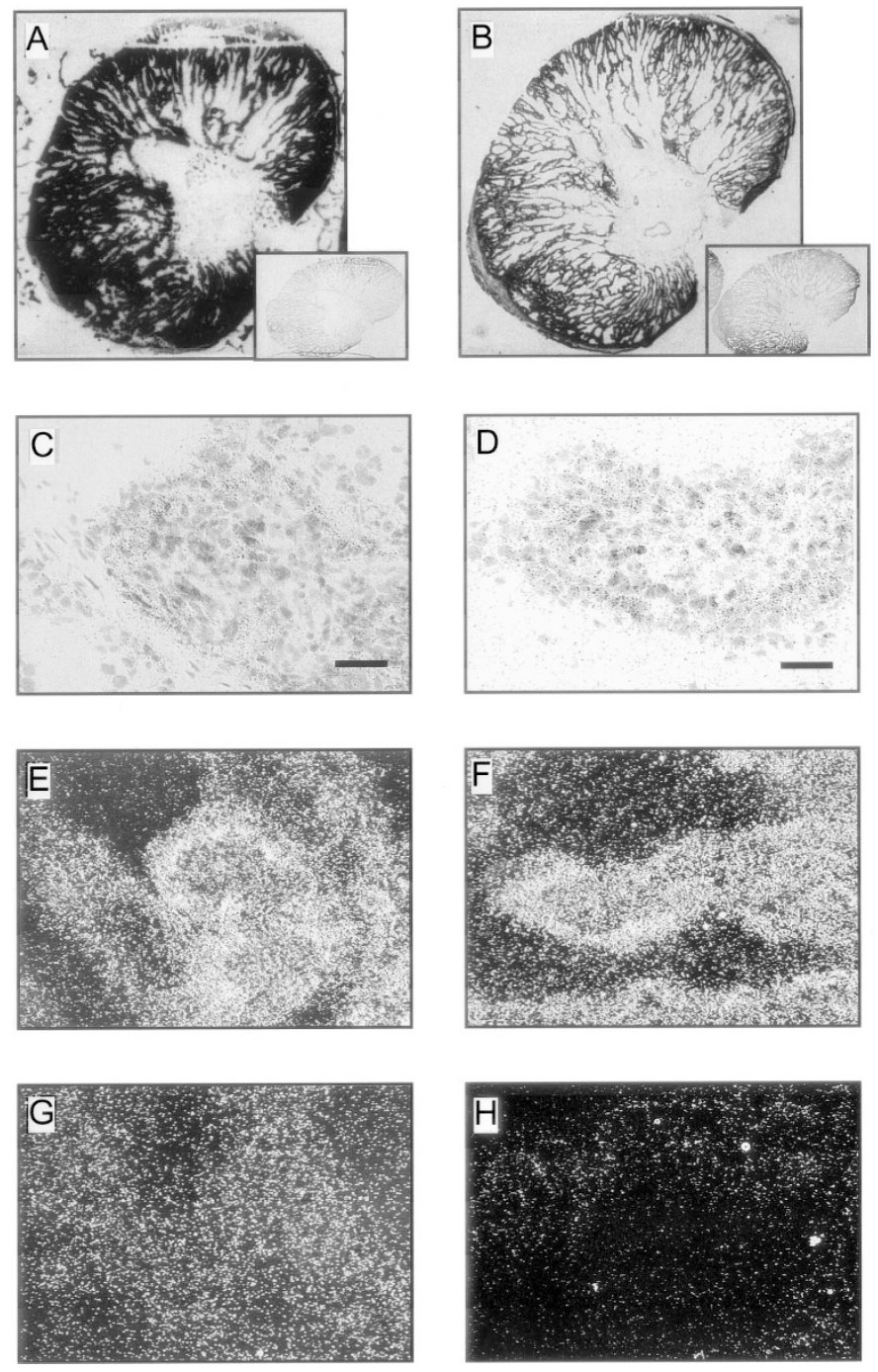

Figure 3. Expression of mcl-1 and bax mRNA in d-81 ovine placenta using in situ hybridization with ${ }^{35}$ S-labeled complementary RNA to ovine mcl-1 and bax. (A, $B$ ) Autoradiograph images showing extensive hybridization of antisense probes to mcl-1 $(A)$ and bax $(B)$ in the placentome. $(C, D)$ Light-field microscopy images showing predominant hybridization of mcl-1 $(C)$ and bax $(D)$ to the maternal-fetal interface. $(E, F)$ Equivalent dark-field images of mcl-1 $(E)$ and bax $(F)$ confirming a higher density of silver grains, indicative of hybridization, over cells comprising the maternal-fetal interface. $(G, H)$ Dark-field sense controls for mcl-1 $(G)$ and bax $(H)$. Scale bar $=100 \mu \mathrm{m}$. Inset $(A, B)$, autoradiography sense controls.

arbitrary units versus $\mathrm{H}: 67,017 \pm 6,961$ arbitrary units; $p>$ 0.1 ). Similarly, bax mRNA expression was highly variable and independent of maternal nutritional treatment group (M: $35,285 \pm 4,797$ versus $\mathrm{H}: 38,057 \pm 3,935 ; p>0.1)$.

Immunolocalization of bax protein in d-80 placentome. Bax protein was localized to cells comprising the maternalfetal interface including the uninucleate trophectoderm but not the binucleate cells (Fig. 4a). Examination of sections at higher power indicated that bax protein was predominantly expressed at the junction of maternal and fetal tissues (Fig. $4 b$ ). This staining pattern was consistent in all placentae examined $(n=28)$.

Quantification of bax protein in d-80 placentas by Western blotting and densitometry. Western blotting for bax revealed a predominant 21,000 Mr band (Fig. 5a). Representative gels for 

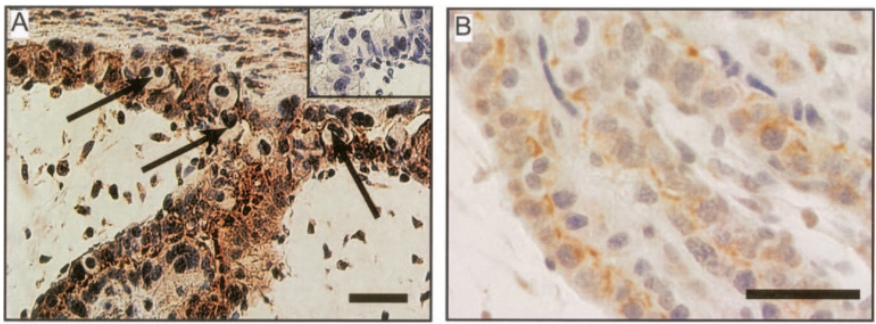

Figure 4. Immunolocalization of bax in $\mathrm{d}-81$ ovine placentome. (A) Bax was localized to the maternal-fetal interface including the uninucleate fetal trophectoderm cells. The binucleate cells were negative (arrows). (B) At high power, bax appears to be concentrated at the junction of maternal and fetal cells. Scale $\mathrm{bar}=100 \mu \mathrm{m}$. Inset, IgG-negative control.
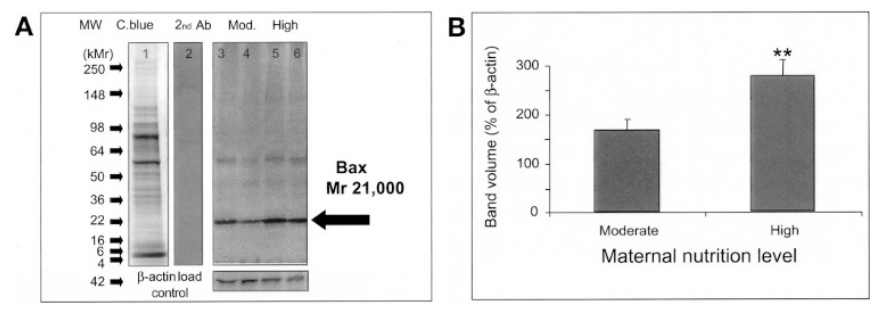

Figure 5. Western blot analysis of bax protein in d-81 placenta from $\mathrm{M}$ and $\mathrm{H}$ animals. (A) Representative gel (lane 1) and Western blots for bax (M: lanes 3, 4; H: lanes 5, 6). Lane 2 = anti-rabbit $\mathrm{IgG}$ (no primary antibody control). The $\beta$-actin load control shows equivalent amounts of protein loaded in each lane. (B) Quantification of band volumes using Phoretix-1D Advanced software (NonLinear Dynamics Ltd.) and significance assessed by the MannWhitney test $\left({ }^{* *} p<0.01\right.$, significantly lower in $\mathrm{H}$ group).

placentas from $\mathrm{M}$ and $\mathrm{H}$ animals are illustrated in Figure $5 a$. No clear nonspecific bands were observed in negative control lanes (secondary antibody only, lane 2). Analyses of the Western blots using Phoretix-1D advanced software (Shimadzu Biotech, Manchester, UK) to measure band volumes (arbitrary units) revealed significantly higher levels of bax protein in the $\mathrm{H}$ group (Fig. $5 b ; p<0.001$ ). Bax protein levels were significantly positively correlated with live weight gain $(\mathrm{g} / \mathrm{d})$ across the whole set of data $\left(r^{2}=0.32, p<0.01\right)$ and in a regression model that fitted a common slope within each group $(p<0.05)$.

\section{DISCUSSION}

We have previously reported that adolescent sheep carrying singleton pregnancies and consuming a high nutritional intake throughout gestation exhibit a major restriction in placental mass at term, leading to a significant decrease in lamb birth weight (8). This phenomenon is specific to growing adolescent sheep and, within groups $\mathrm{M}$ and $\mathrm{H}$, placental and fetal mass are highly correlated $(9,10)$. We have investigated developmental changes occurring in the placenta at $\mathrm{d} 81$ of gestation (term $=$ $145 \mathrm{~d}$ ), which is coincident with the predicted apex in placental growth (19). At this developmental time point the total wet mass of the placentomes was equivalent in the $\mathrm{H}$ and $\mathrm{M}$ groups. Nevertheless, we have shown that d-81 placentas from animals on the high-intake diet exhibit a significantly reduced level of proliferative activity in the fetal trophectoderm and a significantly increased protein level of bax; a pro-apoptosis gene product of the bcl-2 family. Although there was no difference in placental mass at this mid-gestation time point, we have previously reported that at late gestation and at term, animals consuming a high intake throughout pregnancy show a $33-45 \%$ reduction in placental mass, compared with control placentas $(10,30)$. We propose therefore that these developmental changes at $\mathrm{d} 81$ of gestation, representing the placental growth phase of pregnancy, might characterize placentas that are already destined to grow in different trajectories.

In the human, IUGR is associated with increased placental apoptosis (14-17), the altered expression of apoptosis regulatory genes, e.g. bcl-2 and p53 (16,17,31), and histopathologic changes including alterations in stem villus blood vessels and elongated terminal villi $(18,32,33)$. Two mechanisms have been proposed to explain these observations. The first is that the histopathological changes result in localized hypoxia, which increases placental apoptosis (14). The second proposes that the anatomical changes occur to enhance nutritional transport and gas exchange to the benefit of the growing fetus (34). Hypoxia induces apoptosis in a range of different tissues, and intermittent placental perfusion in vitro induces apoptosis in the syncytiotrophoblast (35). In the adolescent sheep model, there is no evidence that the placenta is hypoxic, however, intermittent placental perfusion may be a factor.

Altered placental proliferation and possibly apoptosis may be secondary to altered maternal and placental hormone levels. For example, in the d- 80 overnourished adolescent, circulating maternal levels of progesterone, $\mathrm{GH}$, placental lactogen, and PSPB are reduced $(10,36,37)$. Inasmuch as the ovine luteoplacental shift occurs at around d 60 (38), these changes likely reflect differences at the maternal-fetal interface. This may negatively impact on placental growth and development. In support of this, progesterone can modulate the expression of bcl-2-related genes in decidual cells and inhibit apoptosis in the lactating mammary gland and ovary (39-41). In addition, placental lactogen inhibits pro-apoptotic caspase 3 mRNA expression in regressing rat decidua (42).

The differences in placental growth that characterize this model are induced by feeding two levels of the same diet. This indicates that the trigger is likely to be an excess of energy or protein. We postulate that this modifies the hierarchy of nutrient partitioning so that maternal growth is promoted at the expense of the developing fetal-placental unit and mammary gland. This may be orchestrated by changes in maternal circulating hormones as described above $(10,36,37)$. In addition, altered angiogenesis resulting in reduced late gestation uterine and umbilical blood flows may also be important $(30,43)$. Inasmuch as overfeeding adult pregnant sheep of identical genotype stimulates adiposity to the same degree as in adolescents but has no effect on placental size or lamb birthweight, altered maternal growth is critical (11). Moreover, because nonpregnant human adolescent growth is associated with endocrine change, e.g. increased IGF and insulin resistance, adolescent pregnancy represents a situation where this status is superimposed on pregnancy-associated endocrine adaptation $(5,44)$. It follows, therefore, that during adolescent pregnancy, the competition between mother and fetus for nutrients is likely to be underscored by inadequate endocrinological adaptation of the mother.

In the ovine placenta, invasive BNC migrate from the fetal trophectoderm through the basement membrane and fuse with 
the maternal epithelium to form a syncytium (45). Although it is unclear whether bax and/or other apoptosis regulators play a role in this process, at the mRNA level, both bax (proapoptotic) and $m c l-1$ (antiapoptotic) are expressed at the maternal-fetal interface. Because mcl-1 antagonizes bax, it is possible that these two genes may interact in the ovine placentome (46). This hypothesis awaits the investigation of placental mcl-1 protein, which is dependent on the generation of an ovinespecific or highly cross-reactive antibody. By Western blot, we have tested a range of anti-Mcl-1 antibodies, and only at the absolute limit of detection have we detected a very lightly stained $38 \mathrm{kD}$ band (Lea et al., unpublished data).

In conclusion, we have demonstrated that, in the overfed adolescent sheep model, the d-81 placenta exhibits reduced proliferation and increased levels of proapoptotic bax protein. We propose that these observations may be a presage of restricted placental growth occurring later in gestation.

Acknowledgments. The authors thank G. Horgan (Biomathematics \& Statistics Scotland, Edinburgh, Scotland) for statistical assistance and the Scottish Executive Environment and Rural Affairs Department for financial support.

\section{REFERENCES}

1. Gortzak-Uzan L, Hallak M, Press F, Katz M, Shoham-Vardi I 2001 Teenage pregnancy: risk factors for adverse perinatal outcome. J Matern Fetal Med 10:393397

2. Jolly MC, Sebire N, Harris J, Robinson S, Regan L 2000 Obstetric risks of pregnancy in women less than 18 years old. Obstet Gynecol 96:962-966

3. Cooper LG, Leland NL, Alexander G 1995 Effect of maternal age on birth outcomes among young adolescents. Soc Biol 42:22-35

4. Stevens-Simon C, Beach RK, McGregor JA 2002 Does incomplete growth and development predispose teenagers to preterm delivery? A template for research. J Perinatol 22:315-323

5. Scholl TO, Hediger ML, Schall JI 1997 Maternal growth and fetal growth: pregnancy course and outcome in the Camden Study. Ann N Y Acad Sci 817:292-301

6. Regnault TR, Galan HL, Parker TA, Anthony RV 2002 Placental development in normal and compromised pregnancies-a review. Placenta 23 Suppl A:S119-S129

7. Heinonen S, Taipale P, Saarikoski S 2001 Weights of placentae from small-forgestational age infants revisited. Placenta 22:399-404

8. Wallace JM, Aitken RP, Cheyne MA 1996 Nutrient partitioning and fetal growth in rapidly growing adolescent ewes. J Reprod Fertil 107:183-190

9. Wallace JM 2000 Nutrient partitioning during pregnancy: adverse gestational outcome in overnourished adolescent dams. Proc Nutr Soc 59:107-117

10. Wallace J, Bourke D, Da Silva P, Aitken R 2001 Nutrient partitioning during adolescent pregnancy. Reproduction 122:347-357

11. Wallace JM, Milne JS, Leitch N, Aitken RP 2003 Overnourishing singleton bearing adult ewes stimulates adiposity but does not influence nutrient partitioning to the gravid uterus. Pediatr Res 53(suppl 2):38A

12. Scholl TO, Hediger ML 1993 A review of the epidemiology of nutrition and adolescent pregnancy: maternal growth during pregnancy and its effect on the fetus. J Am Coll Nutr 12:101-107

13. Lea RG 2001 Proliferation, differentiation and apoptosis in pregnancy and cancer. In: Barnea ER, Jauniaux E, Schwartz PE, Schofield PN (eds) Cancer and Pregnancy. Springer Verlag, London, pp 216-228

14. Smith SC, Baker PN, Symonds EM 1997 Increased placental apoptosis in intrauterine growth restriction. Am J Obstet Gynecol 177:1395-1401

15. Erel CT, Dane B, Calay Z, Kaleli S, Aydinli K 2001 Apoptosis in the placenta of pregnancies complicated with IUGR. Int J Gynaecol Obstet 73:229-235

16. Kudo T, Izutsu T, Sato T 2000 Telomerase activity and apoptosis as indicators of ageing in placenta with and without intrauterine growth retardation. Placenta 21:493-500

17. Ishihara N, Matsuo H, Murakoshi H, Laoag-Fernandez JB, Samoto T, Maruo T 2002 Increased apoptosis in the syncytiotrophoblast in human term placentas complicated by either preeclampsia or intrauterine growth retardation. Am J Obstet Gynecol 186:158-166

18. Chen CP, Bajoria R, Aplin JD 2002 Decreased vascularization and cell proliferation in placentas of intrauterine growth-restricted fetuses with abnormal umbilical artery flow velocity waveforms. Am J Obstet Gynecol 187:764-769

19. Ehrhardt RA, Bell AW 1995 Growth and metabolism of the ovine placenta during mid-gestation. Placenta 16:727-741
20. Rusell AJ, Doney JM, Gunn RG 1969 Subjective assessment of body fat in live sheep. J Agric Sci 72:451-454

21. Zheng J, Johnson ML, Redmer DA, Reynolds LP 1996 Estrogen and progesterone receptors, cell proliferation, and c-fos expression in the ovine uterus during early pregnancy. Endocrinology 137:340-348

22. Jablonka A, Fricke PM, Redmer DA, Reynolds LP 1991 Bromo-deoxyuridine (BrdU) immunohistochemistry to evaluate labelling index of tissue in vivo. In: Dziuk PJ, Wheeler MB (eds) Handbook of Methods for Study of Reproductive Physiology in Domestic Animals. University of Illinois, Urbana, IL, pp 1-2

23. Lea RG, Howe D, Hannah LT, Bonneau O, Hunter L, Hoggard N 2000 Placental leptin in normal, diabetic and fetal growth-retarded pregnancies. Mol Hum Reprod 6:763-769

24. Murray TJ, Fowler PA, Abramovich DR, Haites N, Lea RG 2000 Human fetal testis: second trimester proliferative and steroidogenic capacities. J Clin Endocrinol Metab 85:4812-4817

25. Da Silva P, Aitken RP, Rhind SM, Racey PA, Wallace JM 2002 Impact of maternal nutrition during pregnancy on pituitary gonadotrophin gene expression and ovarian development in growth-restricted and normally grown late gestation sheep fetuses. Reproduction 123:769-777

26. Da Silva P, Aitken RP, Rhind SM, Racey PA, Wallace JM 2003 Effect of maternal overnutrition during pregnancy on pituitary gonadotrophin gene expression and gonadal morphology in female and male foetal sheep at day 103 of gestation. Placenta 24:248-257

27. Mitchell SE, Robinson JJ, King ME, McKelvey WA, Williams LM 2002 Interleukin 8 in the cervix of non-pregnant ewes. Reproduction 124:409-416

28. Leo CP, Hsu SY, Chun SY, Bae HW, Hsueh AJ 1999 Characterization of the antiapoptotic Bcl-2 family member myeloid cell leukemia-1 (Mcl-1) and the stimulation of its message by gonadotropins in the rat ovary. Endocrinology 140:5469-5477

29. Akcali KC, Khan SA, Moulton BC 1996 Effect of decidualization on the expression of bax and bcl-2 in the rat uterine endometrium. Endocrinology 137:3123-3131

30. Wallace JM, Bourke DA, Aitken RP, Leitch N, Hay WW Jr 2002 Blood flows and nutrient uptakes in growth-restricted pregnancies induced by overnourishing adolescent sheep. Am J Physiol Regul Integr Comp Physiol 282:R1027-R1036

31. Levy R, Smith SD, Yusuf K, Huettner PC, Kraus FT, Sadovsky Y, Nelson DM 2002 Trophoblast apoptosis from pregnancies complicated by fetal growth restriction is associated with enhanced p53 expression. Am J Obstet Gynecol 186:1056-1061

32. Wilhelm D, Mansmann U, Neudeck H, Matejevic D, Vetter K, Graf R 2002 Decrease of elastic tissue fibres in stem villus blood vessels of the human placenta during IUGR and IUGR with concomitant pre-eclampsia. Anat Embryol (Berl) 205:393-400

33. Krebs C, Macara LM, Leiser R, Bowman AW, Greer IA, Kingdom JC 1996 Intrauterine growth restriction with absent end-diastolic flow velocity in the umbilical artery is associated with maldevelopment of the placental terminal villous tree. Am J Obstet Gynecol 175:1534-1542

34. Nelson DM 1996 Apoptotic changes occur in syncytiotrophoblast of human placental villi where fibrin type fibrinoid is deposited at discontinuities in the villous trophoblast. Placenta 17:387-391

35. Hung TH, Skepper JN, Charnock-Jones DS, Burton GJ 2002 Hypoxia-reoxygenation: a potent inducer of apoptotic changes in the human placenta and possible etiological factor in preeclampsia. Circ Res 90:1274-1281

36. Wallace JM, Da Silva P, Aitken RP, Cruickshank MA 1997 Maternal endocrine status in relation to pregnancy outcome in rapidly growing adolescent sheep. J Endocrinol $155: 359-368$

37. Wallace JM, Aitken RP, Cheyne MA, Humblot P 1997 Pregnancy-specific protein B and progesterone concentrations in relation to nutritional regimen, placental mass and pregnancy outcome in growing adolescent ewes carrying singleton fetuses. J Reprod Fertil 109:53-58

38. Al-Gubory KH, Solari A, Mirman B 1999 Effects of luteectomy on the maintenance of pregnancy, circulating progesterone concentrations and lambing performance in sheep. Reprod Fertil Dev 11:317-322

39. Dai D, Moulton BC, Ogle TF 2000 Regression of the decidualized mesometrium and decidual cell apoptosis are associated with a shift in expression of $\mathrm{Bcl} 2$ family members. Biol Reprod 63:188-195

40. Berg MN, Dharmarajan AM, Waddell BJ 2002 Glucocorticoids and progesterone prevent apoptosis in the lactating rat mammary gland. Endocrinology 143:222-227

41. Svensson EC, Markstrom E, Shao R, Andersson M, Billig H 2001 Progesterone receptor antagonists Org 31710 and RU 486 increase apoptosis in human periovulatory granulosa cells. Fertil Steril 76:1225-1231

42. Tessier C, Prigent-Tessier A, Ferguson-Gottschall S, Gu Y, Gibori G 2001 PRL antiapoptotic effect in the rat decidua involves the PI3K/protein kinase B-mediated inhibition of caspase-3 activity. Endocrinology 142:4086-4094

43. Wallace JM, Bourke DA, Aitken RP, Milne JS, Hay WW Jr 2003 Placental glucose transport in growth-restricted pregnancies induced by overnourishing adolescent sheep. J Physiol 547:85-94

44. Amiel SA, Caprio S, Sherwin RS, Plewe G, Haymond MW, Tamborlane WV 1991 Insulin resistance of puberty: a defect restricted to peripheral glucose metabolism. J Clin Endocrinol Metab 72:277-282

45. Hoffman LH, Wooding FB 1993 Giant and binucleate trophoblast cells of mammals. J Exp Zool 266:559-577

46. Leo CP, Hsu SY, Chun SY, Bae HW, Hsueh AJ 1999 Characterization of the antiapoptotic Bcl-2 family member myeloid cell leukemia-1 (Mcl-1) and the stimulation of its message by gonadotropins in the rat ovary. Endocrinology 140:54695477 